\title{
DIRECT VS INDIRECT ELECTION TO GRAMA PANCHAYAT PRESIDENT: REFLECTIONS AND IMPLICATIONS
}

\begin{abstract}
This discussion paper is a qualitative analysis built on opinions. Though there is no one-to-one link between performance and service delivery of grama panchayats (GPS) and method of election to GP president, the paper talks about opinions, which support direct election. There is a discussion going on at the policy level in States like Karnataka whether to go in for direct election of the president of the gram panchayat or not. Although the overall preference of stakeholders and people is for direct election, the empirical data and the opinions of those with whom we interacted fail to clearly bring out the justification for direct or indirect election of GP president. The reasons are many: the differences in structure and size of the panchayats across selected States, linkages with higher level of $P R I s$, their financing mechanism and devolution of powers. In the absence of counterfactuals with similar panchayati rajsystem in States with direct election it is difficult to say which system is better than the other. Though the differences are not very significant, resource mobilisation, efficiency in delivery of services and utilisation of funds appear to be better in States with direct election. And, quick decisions, higher social auditing, higher social equity, satisfaction with election system and low incidence of no-confidence motion, dominance of caste are also the features noted in States with direct election. On the other hand, cooperation and collective decision, weightage to the institution rather than the individual, competition among members for getting benefits to their wards are some of the merits of indirect election. After weighing the merits of both the systems, direct election clearly stands out as a preferred system.
\end{abstract}

N. Sivanna*

Nayanatara Nayak ${ }^{* *}$

Narayan Billava

and

V.T. Hungund ${ }^{* * *}$

*Adjunct Professor and Head, CPIGD, ISEC, Bengaluru.

**Professor, CMDR, Dharwad.

***Research Officers, CMDR, Dharwad.

This paper is based on the data collected for the larger study "Pros and Cons of Direct Election for Grama Panchayat President" conducted by CMDR, Dharwad and Sponsored by Department of Rural Development and Panchayat Raj, Government of Karnataka. The authors are thankful to Government of Karnataka for funding this study and acknowledge the academic support in terms of information gathering and report writing received from Prof. P.R.Panchamukhi, Chairman, CMDR, Dharwad; Prof. Abdul Aziz, NLS, Bengaluru; Prof. M. Gopinath Reddy, CESS, Hyderabad; Dr. Ganesh Prasad, SIRD, Mysore; Dr. Upendra Singh, CDECS, J aipur; Dr. Madhusudan Bandi, GIDR, Ahmedabad and Mr. Nayakara Veeresha, PhD Scholar, ISEC for academic assistance. 


\section{Context}

The debate over an ideal method of election has always been alive ever since the democratic political system emerged. There are innumerable modes available in the world where one or the other is practised and yet none providesa solution to all the requirements. In the context of decentralised governance, one question that continues to be relevant is how effective is direct election of the Grama Panchayat (GP) president in delivering development services to the poor in rural India. No doubt, $73^{\text {rd }}$ and $74^{\text {th }}$ Constitutional Amendments of 1992 enabled fundamental reforms at the grassroots of development administration. So much so, they opened up larger space for people to participate and determine the trajectory of improvement of their well-being. While several forces have been at work since time immemorial against the poor and the disadvantaged, a participatory developmentmechanism as conceived under the auspices of the constitutional amendments mentioned above is envisaged to counter such forces. It is in this context that one needs to understand the efficacy of introducing direct election of the GP president, the leader who brings the people together under a common shade to perform and achieve what is valued at the level of social aggregation.

The discussion in this paper addresses a specific issue which has great potential both in theory and practice of democracy. The issue relates to two different methodsfor electing the president of a GP. That poses a question 'should the president of the GP be elected by the members of the panchayat or by the people directly'? This obviously is an empirical issue. However,one can consider its specific theoretical dimensions also. Preferences of the people through a ballot box, a method of secret expression of preferences, without revealing the identity of the expresser or through voice voting or by raising of hands, etc., can be considered as open methods of preference revelation. All these are the instrumentalities of public choice.

In other words, people choose a particular option through these methods of preference revelation. Election, the modusoperandi of public choice, thus is the sine qua non of democracy. Election as a method of decision making about any issue can take several forms such as election by the people directly or election by the representatives of the people or election by a group so designated to its preference on behalf of the people. When numbers are large, such proxies of choice by a smaller group said to represent the large numbers of people are adopted with obvious limitations. Another major issue of public choice in a democracy is the aggregation of preferences of the people so that clear signals are derived to select a particular alternative out of several alternatives or choose a particular option in a binary framework, all based upon the preferences of the people. No political affiliation or personal prejudice or power lobby works if people are given a choice to choose a candidate based on the credentials established by him/her in public life. The rationale for having set in motion the process of direct election of the development leader at the grassroots is that it values development of all, especially of the needy defying traditional power relations. Governments in Karnataka, Punjab and Kerala have been talking about direct elections to GP president. 


\section{Review of Literature}

There are a few reviews that favour direct democracy. According to Matsusaka (2004), direct democracy has two main virtues: first, direct democracy allows voters a way to circumvent representative institutions that may have been captured by elites or other special interests. Second, compared with meetings, elections allow an order of magnitude for more citizens to participate directly in political decision making. And thisincreased participation issaid to enhance the legitimacy of political decisions even if the decisions themselves do not change (Lind and Tyler, 1988 quoted by Olken, 2010:243).

For example, voters are said to be more competent and the relationship between money and power in direct democracy is reported to be less reprehensible than many observers allege. More new studies show that the mere presence of direct democracy induces sitting legislatures to govern more effectively (Lupia and Matsusaka, 2004). Altman (2014:i) summarises the prospects of direct democracy with the challenges involved as "The embrace of direct democracy is costly, may generate uncertainties and inconsistencies and in some cases is easily manipulated. Nonetheless,the promise of direct democracy should not be dismissed. Direct democracy is much more than a simple, pragmatic second choice when representative democracy seems not to be working as expected. Properly designed, it can empower citizens, breaking through some of the institutionalised barriers to accountability that arise in representative systems."Direct participation in political decision making can substantially increase satisfaction and legitimacy, even when it has little effect on actual decisions (Olken, 2010). Elected regulators produce more pro-consumer policies (Formby,Mishra and Thistle, 1995; Fields, Klein and Sfiridis, 1997). Formby,
Mishra and Thistle (1995), in their investigation on the extent to which political factors (which vary across State Public Utility Commissions) affect electric utility bond ratings, found that the 'elected regime' negatively influences the cost of capital of electric utilitiesusing data from 19791983 on a selection of investor-owned utilities. Fields, Klein and Sfiridis (1997) also find that the market value of life insurance companies declined when the selection of insurance commissioner was changed from appointment to election as they were found to be more proconsumer. In China, direct elections effected by electoral reforms have brought about significant changes in popularly elected village committees (Gang, 1999).

\section{Focus}

In this context, the methods of election are grouped as'direct'and 'indirect'elections. The broader understanding of direct election is, election of representatives by the voters themselves- the candidate receiving the highest number of votes is declared as elected president. In indirect elections, the voters from smaller constituencies (wards in the case of panchayats in rural India) choose their representatives who in turn choose their president amongst themselves by majority voting. In States like Gujarat,Tamil Nadu,Andhra Pradesh, Rajasthan, Odisha, Bihar and Haryana, direct election of the GP president is in practice and in the remaining States indirect election is in vogue. In case there is no other contestant for the seat of panchayat president, villagersunanimously elect a candidate without voting. However, the unanimous system of election is not spelt out in the Constitution of India. Gujaratfollows a kind of unanimous election system known as "samras" which is also encouraged by the Government of Gujarat. In one of the taluks, in the last election held, about 
70 per cent of panchayat presidents are reported to have been elected under unanimous election system ${ }^{1}$.

Under the Karnataka Panchayat Raj Act, the president of the GP is elected by the elected GP members indirectly. Although this has been the practice right from the introduction of the 1983 Act, of late there have been some disturbing developments with regard to the election of the president. As per Section 46 of 1993 Act, the term of office of every president and every vicepresident of GP is for a period of 30 monthsfrom the date of his/her election. As per the recent amendments to the Karnataka Panchayat Raj Act (Amendment Bill, 2015) ${ }^{2}$, the tenure has been raised from 30 months to 5 years. Stability of tenure is one of the most critical elements in developing the villages in order to improve local governance. However, as has been reported in the media and also from the field level studies, there have been frequent changes to the office of president and this has been done through an internal understanding and adjustment. As a consequence, the period of 30 months is being shared by the GP members who occupy the seat of president to relish the power for every six months thereby destabilising the GP system and its governance. On an average, two to three members, for a prescribed period, are being elected to the office of president during the period of 30 months. These unprecedented developments of frequent changes to the position of GP president through no-confidence motion and adjustments have been causing uncertainties and coming in the way of effective functioning of GPs in the State. Set in this backdrop, the Karnataka government has initiated discussions on direct election to the office of president of GP to find out whether change in the system will ensure stability and continuity and its better performance.

In this background, the research agenda isto lookinto two types of election systems, direct and indirect, for electing the GP president in selected States, their linkages, if any, with the governance and delivery of services, documenting merits and demerits of them based on the reports from selected GPsand perceptions of stakeholders (presidents/ vice-presidentsand members of GPs, PDOs/secretaries and people). The broader issue of this study is to understand what method of election provides for a near perfect reflection of people's will (eligible voters) to choose the candidate of their choice as president.

\section{Methodology}

The study covers six States viz., Karnataka, Tamil Nadu,Andhra Pradesh, Haryana, Rajasthan and Gujarat. Among the selected States, Gujarat, Rajasthan, Haryana, Andhra Pradesh and Tamil Nadu have direct election systems, while Karnataka has indirect election for the selection of GP president. In each State, we have selected two districts representing different regions and from each district one GP.

In Karnataka, eight districts (two districts from each of the four administrative divisions) viz.,Gulbarga, Raichur, Belgaum, Dharwad, Ramnagar, Kolar, Mysore and Udupi were selected covering a total of $8 \mathrm{GPs}$ (one in each district). The GPs in each State were selected in consultation with the officials and the representatives of ZP/TP, on the basis of their performance, delivery of services, tax collection, administrative work, status pertaining to moving of no-confidence motion and self- resignation and other related issues. 
The primary data required for the study were gathered through GP documents, one-toone discussion with stakeholders and NGOs and focus group discussions with villagers in 2012. We placed a hypothetical situation of direct election before the GP members in Karnataka and asked them to present their views on its pros and cons in comparison to the benefits and flaws of the existing system. The discussion was initiated using a checklist with open-ended questions focusing on the relevance of gram sabha, satisfaction over the existing system of election, expectations of villagers from the president, implementation of programmes in the village, extent of transparency in the activities of the gram panchayat, influence of caste in elections, money power, their participation in gram sabha, opinion on introducing direct election to GP president and functioning of the proposed system, etc., with people represented by political parties, village elders, women and youth. Perceptions of selected NGOs working on PRIs were gathered through telephonic survey with close-ended questions as to whether they prefer direct or indirect election and if so why.

\section{Findings}

A question linked to election method was raised before the stakeholders to respond whether they were satisfied with the system of election that existed in their respective States. While majority in other States with direct election system were happy with the system, in Karnataka with indirect election for GP president, only 40 per cent of selected respondents (Figure 1) expressed their satisfaction about the present system of electing the president indirectly through members. They felt that under indirect system, the president will consider the suggestions and advice of GP members as he/ she is elected by them. There is lesser spending on elections and lesser chances of leaders from dominant groups in the village capturing power, which are likely to be higher under direct election.

\section{Figure 1: Satisfaction with the Present Method of Electing the President (Percentage)}

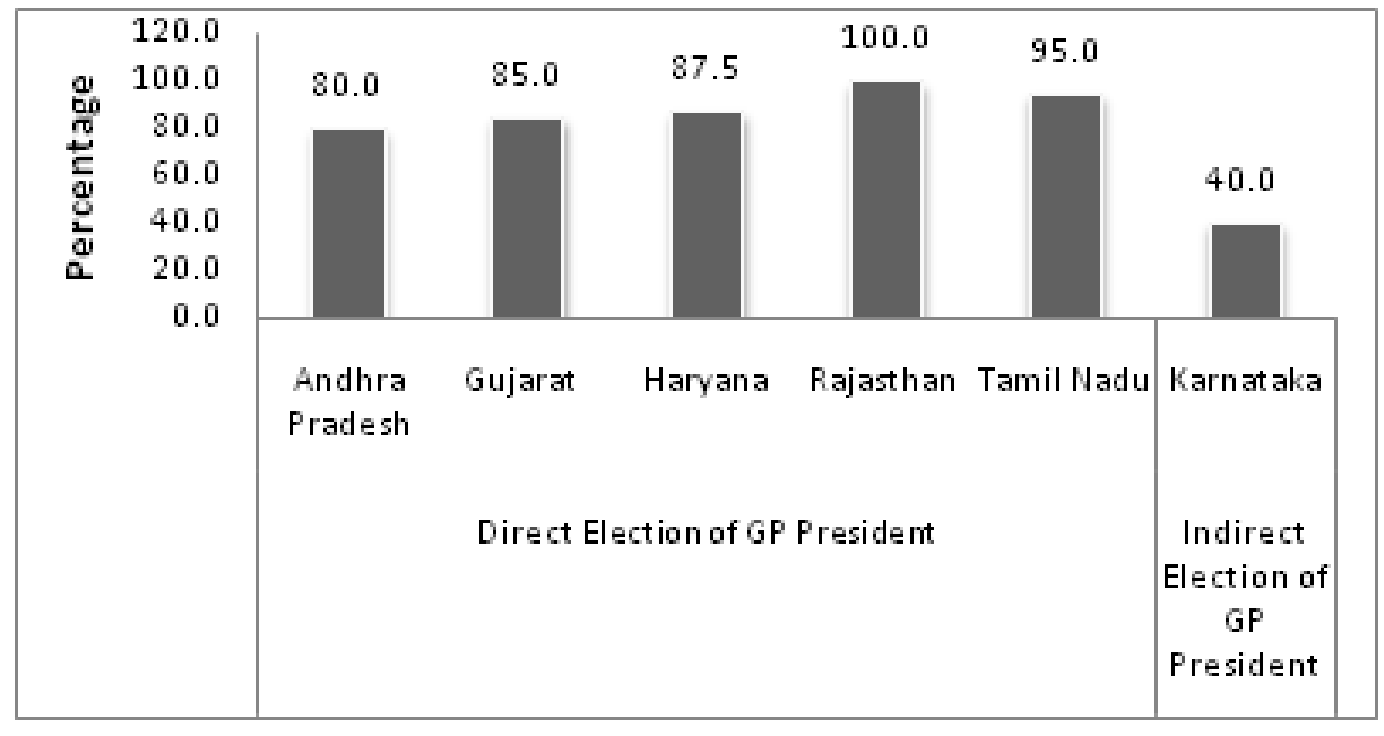

Journal of Rural Development, Vol. 36, No. 2, April - June : 2017 
Further, in Karnataka stakeholders were asked whether people should be given a chance to elect their panchayat president instead of indirect election by the members. Based on their current experience, 78 per cent of the respondents (Figure 2) said that direct election for GP president is a better option for the State. Thisgroup of residents also included respondents who expressed satisfaction over current indirect method of election. May be they felt that direct elections would result in better administration. Two of the main reasons for favouringdirect elections were the provision of fixed tenure enabling the president to take up activities for long-term benefits and the appointment of president by public choice, which in turn would act as a barricade in passing no-confidence motion against the president giving stability to the system. Although there was skepticism about the working of direct election system, there was a clear preference to direct election system in selected GPs of eight districts of Karnataka viz., Dharwad, Mysore, Udupi, Raichur, Gulbarga, Belgaum, Kolar and Ramnagar.

Figure 2: Is Direct Election of GP President a Better Option to Karnataka State? (Percentage)

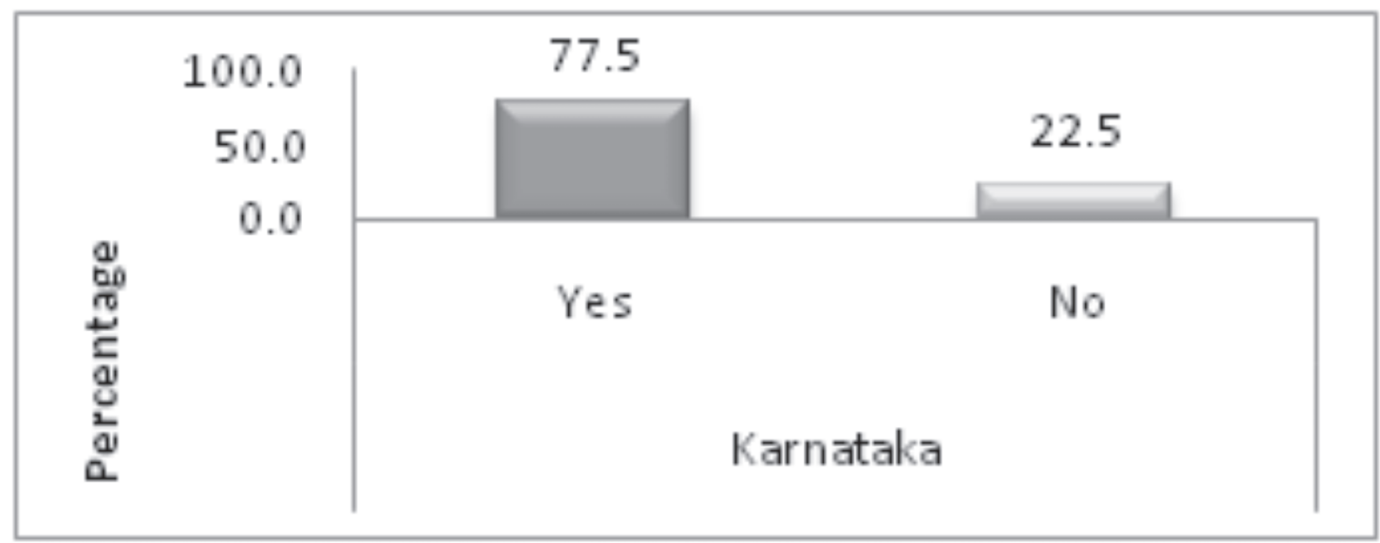

The experience of States with direct election presents a mixed scenario. Andhra Pradesh has been having a directelection system to the post of GP president for fairly a long time. An assessment by the research team on the efficacy of the present system clearly reveals that the direct election has stood the test of the time and most of the stakeholders are in favour of the system and want the system to continue in future as well. It has come out strongly that the GP president attainsenhanced legitimacy if he/she is elected directly by the peopleand can discharge the functions in a fairly transparent manner. According to Behar (2003:183) the opportunities presented by the Madhya Pradesh State's experiment of Gram Swaraj has the potential of ensuring direct democracy. But under direct election system, the GPsin Andhra Pradesh have also assumed the dubious name that they are president-centric with a very nominal role for GP members in the affairs of the village. Reducing the role of GP members in the village affairs does not hold good for the democracy as they are also equally responsible for the development of the village. In terms of leveraging the resources, the elected GP president directly scores over the one indirectly elected. Villagers feel that a GP president can be made more accountable if he/ 
she is elected directly by the public than through indirect method. Of course, the leadership skills and the dynamic nature of the leadership also matter in the delivery of services to the people as reported by the respondents. The findingsfrom the sample villages reveal that development has not been equitable where the GPs lacked dynamism, drive and motivation. In order to bring the dynamism into the grama panchayat to function as "institution of self-government", the State government should devolve the necessary powers to carry out the local affairs including the developmental works. The functionaries like village secretaries and mandal development officers in AP also held the view that direct election is a better method in the effective implementation of the programmes.

In Gujarat, every voter (respondent) views direct election to GP president as the ultimate option over theindirect method. Under the direct method of election, the respondents see their direct role and a platform to express themselves with free will. However, the situation becomes tricky with the emergence of the phenomenon of 'samras',which refers to unopposed election of the GP president. Theoretically, this phenomenon appears sound - for it presents a picture of pro-democracy where the voters in the constituency back a candidate unanimously even without election. But the study reveals that in a very specific kind of atmosphere where the cohesiveness in the GP is absolute, it seems to work well. Notwithstanding the above, most of the voters believed that this in fact is undemocratic because it allows the powerful elite to impose their dictate on the rest of the voters in return for the monetary incentives from the government (given as a token of encouragement for following samras).Similarly, the claims of samras maintaining peace in the villages prove empty because the discontent always remains when the president is unfairly imposed upon the electorate through samras or even elected through deceit. A glaring outcome of the study is that the people do not wish to have samras imposed by the government with the incentives. It would be much better if the State government pays attention to build the capacities of the panchayats rather than providing incentives through samras. This according to them createsunnecessary pressure on the voters. Being the smallest unit of democracy in India, many of the aspirants would like to take part in the public life and contribute to their village in some way. But the aspirations of the people, especially the weaker sections are found to be nipped in the bud.

The post of the vice-president to GP is abolished in Haryana as such the president of GP can work without any pressure in the absence of vice-president. Haryana is also not having the provision of no-confidence motion against the GP president. Consequently the president does not feel insecure unlike in other States. Blocklevel administration plays a crucial and important role in Haryana as it is the key agency for implementing all the developmental programmes planned by the non-officials at GP level. It was found that sarpanchs having harmonious relations with BDOs had better coordination with officials. From the information received it was noted that implementation of self-governance/local governance through decentralised process as per the concerned legislation is only on paper at all the three tiers of panchayat administration in Haryana.

In Rajasthan, direct election of the panchayat president is in vogue for a long time. The constitutional amendments took place later. As a result of direct election, the incidences of no-confidencemotionsare very few in Rajasthan. 
The GP president is accountable to people who choose her/him. So, if anything goes wrong, people directly question the president and settle the matter by discussing with her/him. It is found that GP members try to avoid activities that go against public opinion. As a result there is lesser political unrest at the GP level. The experiences in Rajasthan so far favour direct elections to GP president, especially with reference to the element of accountability to the people which is nucleus to the local governance.

In Tamil Nadu, there is not much change in the democratic process at the lowest tier of decentralised experiment. The constitutional amendments and introduction of direct elections have failed to strengthen the GPs. The institutional infrastructure of a community is important, the precise influence that it has on the practice of governance in the community will depend on the individuals' activeness in the institutions concerned and the ways in which they choose to exercise their agency as community leaders (Woods, Edwards, Anderson and Gardener, 2007:214). The direct election of GP president has neither brought voters and the president together nor any improvement in the lives of the people.The old system of bureaucracy continues to play a major role in implementation of panchayat activities. People feel comfortable in discussing issues and programmes with bureaucrats, line departments and other development agents. So there appears to be a limited role for GP president. With this background, it is difficult to count upon Tamil Nadu experience of direct elections to GP president. There are no concrete evidences from Tamil Nadu village politics that favour direct elections or its replication elsewhere. Like many other States, the presidents in Tamil Nadu have been removed through no-confidence motionsor are compelled to resign. Sometimes the resignation could be through mutual understanding among members. The other issue that was looked into was about the financial powers vested with GP presidents. In most of the States GP presidents have become powerful as funds under MGNREGA are directly sent to GPs. As a result, there are also reports about misutilisation of funds or foul play across the country.But, in Tamil Nadu GP presidents or members do not have financial power in this regard. Moreover, the inspector of panchayats has the power to supervise and control panchayat administration and is vested with the powers to remove the president and announce dissolution of the panchayat. This power vested with the inspector in a way cautions GP presidents and members as there is some fear of being removed from the post. Such checksand balances becomenecessary sometimes to control overpowered GP president.

Karnataka, which is having a strong decentralised structurealong with more financial powers given to the panchayats, may need to look at the directelections to the president's post from other perspectives, especially from caste and class angles. These set of factors may prove to be counterproductive and may result in a situation where more powerful people especially feudal landlords and people with money power could capture power in the village and the huge funds available with the panchayats in the State may prove to be lucrative for such people. Caste, class and gender hierarchies have a crucial bearing on institutional processes and democratic practices (Anil Kumar and Mehrotra, 2004: 4141). One may need a proper balancing act in this scenario.

The empirical investigation of Karnataka situation with regard to prosand cons of holding direct election to the office of president does not provide any clear cut direction with reference 
to linkages of election system of GP president to the performance of GPs.Stakeholders are not happy with the functioning of many GPs due to delay in developmental activities on account of frequent change of presidents in some GPs, party politics and decisionstaken in favour of followers. These flaws are the only reasons for seeking a change in the system of election by majority of villagers as well as other stakeholders in Karnataka. It is hoped that the new system i.e., direct election would put an end to disturbances caused by the adjusted resignations and noconfidencemotions.Theempirical probing in this context reveals that there is a consensus emerging from FGDswith villagers that Karnataka should go in for electing their GP presidents directly by the people.

\section{Conclusion}

Although the overall preference of stakeholders and people is for direct election, the empirical data and the opinions of those with whom we interacted fail to clearly bring out the justification for direct or indirect election of GP president. The reasons are the differences in structure and size of the panchayats across selected States, linkages with higher level of PRIs, their financing mechanism and devolution of powers. In the absence of counterfactuals with similar panchayat raj system in States with direct election like that of Karnataka it is difficult to say which system is better than the other. Some of these States have been following one or the other system for years and there is no documentation of before and after scenario. Also it needs to be mentioned that many States that have direct elections are the ones where strong decentralised institutions are not in place. Further, these are also the States where the line departments still play a major role in the implementation of development programmes.
One could also think of Kerala which is currently having indirect election to GP for comparison. But, discussions with experts suggest that in Kerala, the State government has given priority to participatory system where people decide the plan and programmes of GP. Each GP has about 20000 to 30000 population and the entire State has only $990 \mathrm{GPs}$. Majo rity of GPs collect 90 to cent per cent taxes from the people in Kerala. Around nine departments come under the GP, which helps larger participation of people in panchayat activities. Therefore, it was felt that the PRI system in Kerala cannot be compared with other States which have lesser devolution of powers, finances and responsibilities as compared to Kerala.

Overall, one can say that there are flaws and merits in both the systems of elections,some of which are common in all the States. But the empirical data on financing of GPs indicates slightly better performance in terms of resource utilisation in States with direct elections than in Karnataka. When local governments are likely to beaccountable, increasing the resourcesavailable to them through increased federal and State transfers as local revenue is raising which will further improve local government functioning (Mullen, 2012:190).

The empirical findings were analysed in the background of theoretical framework with parametresindicating the justification for PRIs. Although the differences are not very significant resource mobilisation, efficiency in delivery of services and utilisation of funds appear to be better in States with direct election. And, quick decisions, higher social auditing, higher social equity, satisfaction with election system and low incidence of no-confidence motion and dominance of caste are also the features noted in States with direct election. On the other hand, 
cooperation and collective decision, weightage to the institution rather than the individual, competition among members for getting benefits to their wards are some of the merits of indirect election. Influence of family members in GP activities, difficultyin running administration on the part of the uneducated and reserved category presidents and money power are common features of both the systems. State level comparative analysis of the perceptions of stakeholders and people's views reveals that there are no major differences with reference to delivery of services, mobilisation, allocation or utilisation of resources and satisfaction over the performance of GPs between States with direct election and States with indirect election system. It is the individual capacity of the president and the system backed by statutory powers, checks and balances that have sustained the functioning of GPs across the States.

However, the reports of partisan decision making, interference of political parties and flow of money in choosing the president are higher in Karnataka as against dominance of caste and autocracy of the president reported from States with direct election. A major drawback of indirect election system is the instability of the president's tenure (in Karnataka), which is not reported from other States except by 6 per cent of the selected panchayats in Gujarat. Instability has affected development process in some panchayats due to break down of services and lack of understanding on account of short-term of the president in Karnataka. So the main issue impinging the development process is noconfidence motion or resignation by president due to adjustments and agreements among the GP members to share power. The lessons that Karnataka may draw from the above discussions is to put a check on passing no-confidence motion or frequent change of GP presidents by rectifying the procedure and methods that lead to such changes.

This phenomenon can be checked in two ways: one, by introducing direct election of GP president by giving choice and power to the people to elect their leader thereby restricting frequent changes wherein members may hesitate to push the president chosen by the people out of power. And there is also the fear of re-election, which many may not be comfortable with. The other way is to introduce some reforms within the existing system of indirect election by making amendmentsto the Karnataka Panchayat Raj Act to check the removal or resignation of GP president before completion of minimum period. As said earlier, although it is difficult to link development with direct elections, perceptions of the people in selected States and Karnataka indicate that there is preference for directelection in spite of its weaknesses. Bureaucracy favours direct election and so also majority (78 per cent) of stakeholders (president, vice-president, PDOs/ secretaries and GP members), while a few feel reforms can be brought into the existing system. Similar is the response from majority (83 percent) of selected NGOs working in the field of decentralisation.

After weighing the merits of both the systems, direct election clearly stands out as a preferred system. However, in the absence of any unanimous views on whether to go in for direct election or not, the interested State governments may opt for experimenting with it on a pilot basis in selected grama panchayats where the incidence of no-confidence motion or resignation is higher. Others who wereagainst direct elections observe that the proposed model of direct elections might create complications with respect to election process 
as it will require two types of elections for GP at the same time and it's counting thereafter. Further, in the background of organisational structure of PRIs, the proposed model may have to beextended to intermediate panchayat (taluk panchayat) and district panchayat without confining it to GP alone. It is apprehended that there might be numerous instances where the elected president may be from one particular political party/group whereas the majority of the members may be from among some other political formation. In such a situation there might be difficulties in running the affairs of the panchayats.

Based on the discussions with experts in the field, people and stakeholders, the paper makes a case for introducing checks that need to be introduced into the system to prevent autocracy by presidents and misuse of power if direct elections are opted. Alternatively, reforms are required to address the drawbacks of indirect election, in case the respective State government wishes to retain the indirect election system. Looking at the pros and cons of the two patterns of electing the GP president, direct election seems to be the better option. To ensure stability, the tenure of the term of president is proposed to be full five years. In such cases there could be concern about the dominance of communities if there is directelection, wherein the presidentship could last for five years. There is a serious danger that bottom-up processes end-up becoming elitedriven ventures further alienating the more marginal sections of society (Korf,2007:270).This could be checked by reservation to SCS,STs and $\mathrm{OBCs}$, the provision of which is already ensured through the Constitution and State Acts.The other option to check this dominance could be by giving certain powers to vice-president of the GP.To check the misuse of powers there should be provision for recall of a non- functional president by the people through a secret ballot by a majority of three-fourth members of gram sabha within the GP provided that no such process of recall shall be initiated unless a notice is signed by not less than one-third of the total members of the gram sabha and presented to the designated authority (similar to the provisions made in Draft Model Panchayat and Gram Swaraj Act, 2009, Govt. of India). A suggestion for appointing ombudsman to a group of GPs is proposed for the smooth functioning of GP and to maintain harmony with other members of GP.

In order to facilitate the implementation of direct election, in addition to the checks mentioned above, the following issues need to be considered for amendments to the StateActs:

i) provision for direct election

ii) fixing the term of office of the president for 5 years

iii) provision for moving no-confidence motion against the president of GP only after two and half years after the election

iv) the Act should provide for re-election if the remaining term of the president is more than one year and the post should be for the same reserved category

v) if the remaining term is less than one year, the vice-president of GP shall perform the duties of the president for the remaining term of GP.

The possibility of appointing administrators can also be considered in case the term is less than a year (these provisions are available in Panchayat Raj Acts of Tamil Nadu and AndhraPradesh). However, the appointment 
of administrators may not be an alternative as it may increase the stronghold of local bureaucracy on panchayats which violates the spirit of local self-governance. In case the State governments retain ind irect elections they should ensure the following:

(i) Power is given to 3/4 majority and not $2 / 3$ of members to pass no-confidence motion against the president and placing before the gram sabha about charges of any kind of misconduct or misappropriation

(ii) increasing the limit for recalling the president or for passing no-confidence motion from present oneyear to two-andhalf years and

(iii) provision for ombudsman for making investigations and enquiries in respect of charges of corruption or irregularities in the discharge of duties by the president and the implementing authorities (as proposed in draft Model GPAct, 2009)and asprovided in Kerala.

Representative democracy suffers from its reliance on the representative principle and from its vulnerability to seduction by an illicit rationalism- from the illusion that metaphysics can establish the meaning of debatable political terms (Barber, 2003:146-147). Therefore, to conclude the paper suggests that the interested State governments for initiating amendments necessary for introducing direct elections or for introducing reforms within the existing system of indirect elections, depend upon the political will of the State.

\section{Notes}

1. As reported by Block Development Officer,Morbi,Gujarat.

2. http://www.deccanherald.com/content/469063/assembly-okays-bill-making-voting.html accessed on 27.06.2015. 


\section{References}

1. Altman D (2014), “Direct Democracy Worldwide”, Cambridge: Cambridge University Press.

2. Anil Kumar,Vaddiraju and Shagun Mehrotra (2004), "Making Panchayats Accountable,"Economic and Political Weekly, Vol.39,(37):4139-4141.

3. Behar, A (2003), "Experiment with Direct Democracy" in "Decentralization and Local Governments: The Indian Experience'edited by Raghunandan T.R (2012), Orient Blackswan Private Limited, New Delhi.

4. Barber R.Benjamin (2003), "Strong Democracy: Participatory Politics for a New Age," Berkeley, Los Angeles and London: University of California Press.

5. Bardhan, P and D. Mookherjee (2006), “Decentralization and Accountability in Infrastructure Delivery in Developing Countries."Economic Journal,116: 101-27.

6. Bardhan, $\mathrm{P}(2002)$, ,Decentralization of Governance and Development." Journal of Economic Perspectives, $16(4): 185-205$.

7. Fields, Joseph A., Klein, Linda S., and James M. Sfiridis (1997) "A Market Based Evaluation of the Election versus Appointment of Regulatory Commissioners," Public Choice, 92:337-351.

8. Formby John, Mishra Banamber and Thistle Paul (1995),"Public Utility Regulation and Bond Ratings Public Choice," 84 (1-2):119-36.

9. Gang (1999), "Bird in a Cage- Elections in Contemporary China" [Available at Elections in China home.olemiss.edu/ gg/paperhtm/elctchin.htm accessed on 18-9-2014].

10. Korf B, "Governing Bottom-up in Rural Development:The Legitimacy Dilemma”in 'Rural Governance, International Perspectives," Edited by Cheshire L, Higgins V and Lawrence G., (2007), Oxan Routledge.

11. Lupia Arthur and John Matsusaka (2004), "Direct Democracy: New Approaches to Old Questions," Annual Review of Political Science, 7: 463-482.

12. Matsusaka, J. G(2004),"For the Many or the Few: The Initiative, Public Policy and American Democracy,"Chicago: University of Chicago Press.

13. Matsusaka J ohn (2005),"Direct Democracy Works,"Journal of Economic Perspectives,19 (2):185-206.

14. Mohanty P. K Parigi V. K and Vyasulu, Vinod (2004),"Interstate Study on Rural Decentralisation," Centre for Good Governance, Hyderabad [available at http://www.cgg.gov.in/ publicationd own loads 2 a/ inter\%20state $\% 20$ study $\% 20$ on $\% 20$ R ural\%20decentralisation.pdf accessed on 16/1/2013].

15. Musgrave R. (1959),'The Theory of Public Finance," New York, McGraw-Hill Book Company Inc.

16. Mullen D.Rani (2012), "Decentralization, Local Governance, and Social Wellbeing in India: Do Local Governments Matter?,"Oxan Routledge.

17. Olken B. A. (2010), "Direct Democracy and Local Public Goods: Evidence from a Field Experiment in Indonesia,"American Political Science Review,104 (2):243-267. 
18. Rajashekar D, Devendra Babu M. and Manjula R (2011),"Elite and Programme Capture in Karnataka's Panchayats,"Report submitted to National Council of Applied Economic Research (NCAER), New Delhi [available at http://www.ruralgov-ncaer.org/images/event/pdf/ 0_1835088679_Elite_capture_report_(Final_May_28_2011).pdf accessed on 16/1/2013].

19. Richard Cook (2003), "Decentralization and Good Governance," Ottawa, Canada: Forum of Federations.

20. Woods M,Edwards B,Anderson J and Gardner G.,'Leadership in Place:Elites, Institutions and Agency in British Rural Community Governance" In 'Rural Governance International Perspectives, Edited by Cheshire L, Higgins V and Lawrence G' (2007), Oxan Routledge. 